Research Article

Open Access

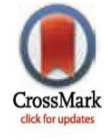

1 Department of Agrotechnology, Faculty of Agriculture, Halu Oleo University, Jl. HEA Mokodompit, Kampus Bumi Tridharma, Anduonohu, Kendari, Southeast Sulawesi, Indonesia.

2 Department of Agronomy and Horticulture, Faculty of Agriculture, Bogor Agricultural University, Jl. Meranti, Darmaga Campus 16680, Indonesia.

3 Department of Soil Science and Land Resources, Faculty of Agriculture, Bogor Agricultural University, Jl. Meranti, 16680 Campus Darmaga, Bogor , Indonesia.

4 Center for Research and Development of Biotechnology and Genetic Resources (BB-Biogen), Jl. Tentara Pelajar No. 3 A Cimanggu, Bogor, Indonesia.

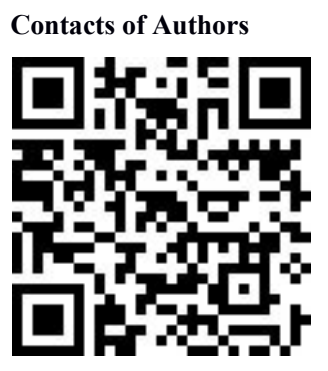

* To whom correspondence should be addressed: La Ode Afa

Citation: Afa L, Purwoko BS, Junaedi A, Haridjaja O, Dewi IS (2020). Growth and yield of new hybrid rice in irrigated and rain-fed lowlands. Highlights in BioScience Volume 3. Article ID 20217.dio:10.36462/H.BioSci.20217

Received: June 6, 2020

Accepted: August 20, 2020

Published: August 31, 2020

Copyright: (C) 2020 Afa et al. This is an open access article distributed under the terms of the Creative Commons Attribution License, which permits unrestricted use, distribution, and reproduction in any medium, provided the original author and source are credited.

Data Availability Statement: All relevant data are within the paper and supplementary materials

Funding: The authors have no support or funding to report.

Competing interests: The authors declare that they have no competing interests.

\section{Growth and yield of new hybrid rice in irrigated and} rain-fed lowlands

\author{
La Ode Afa ${ }^{1 *}$, Bambang S. Purwoko ${ }^{2}$, A. Junaedi ${ }^{2}$, Oteng Haridjaja ${ }^{3}$ and \\ Iswari S. Dewi ${ }^{4}$
}

\section{Abstract}

Two experiments were conducted at (i) irrigated lowland, village of Bojong, Cikembar, Sukabumi Sub-district, Indonesia, from November 2011 to February 2012, and (ii) rain-fed lowland, village of Sanca, Gantar sub-district, Indramayu, Indonesia, from April to July 2012. The objective of the experiment was to determine the yield of drought-tolerant hybrid rice genotypes. A randomized block design with three replications was used. The treatment consisted of 8 hybrid rice genotypes (BI485A/BP3, BI485A/BP5, BI485A/BP10, BI485A/BP12, BI485A/BP15, BI599A/BP5, BI599A/BP15 and BI665A/BP6) and 2 check varieties (Hipa 7 and Ciherang) for the experiment in irrigated lowland, 4 hybrid genotypes (BI485A/BP3, BI485A/BP12, BI485A/BP15 and BI599A/BP15) and 3 check varieties (Hipa 7, IR64 and Limboto) for the experiment in rain-fed lowland. On irrigated lowland, all tested-genotypes produced grain yield per hectare, which was not significantly different from the check varieties Ciherang and HIPA 7. The yield of genotype BI485A/BP12, BI485A/BP15 and BI559A/BP15 under irrigated lowland showed non-significant different with check varieties Ciherang and Hipa 7, i.e 5.63, 6.87, and 6.30 tons $\mathrm{ha}^{-1}$, respectively. Genotype BI599A/BP15 under severe drought rain-fed lowland yielded 0.90 tons of grain $\mathrm{ha}^{-1}$, whereas Hipa 7 (hybrid variety, suitable for rain-fed lowland) and Limboto (drought-tolerant check variety) reached 0.34 and 0.29 tons $\mathrm{ha}^{-1}$, respectively. Genotype BI599A/BP15 is a new hybrid genotype that potential for advanced development in rain-fed lowland and in irrigated lowland with a high yield potential and quiet early-maturity age.

Keywords: yield, hybrid rice, irrigated lowland, rain-fed lowland.

\section{Introduction}

Hybrid rice is an alternative technology to increase rice productivity. Research results in several tropical countries showed that hybrid rice had more yield advantages than inbred rice with more than one ton per hectare [1]. One component of the success of hybrid rice development is the availability of excellent varieties that have high heterosis and can increase yield potential by $15-20 \%$ [1,2]. Experiments on the yield of hybrid rice from 1982 to 2011 showed more advantages than inbred rice in terms of productivity of dry grain and age $[2,4,5]$. The experiment is continuously conducted to improve rice production by assembling high-yield potential, earlier mature and drought tolerant hybrid rice for marginal land such as the rain-fed lowland. The new hybrid genotypes that potential to be developed in the rain-fed areas have been identified through a series of tests in a controlled environment. Tests using PEG 6000 and drought stress on nutrients culture in seedling phase and in pot and simulation in the field have successfully identified drought-tolerant hybrid rice genotypes, namely BI485A/BP12, BI485A/BP15, and BI559A/BP15 genotypes [6,7]. 
The genotypes need to be tested on in-situ conditions (field test) to obtain hybrid rice genotypes with high yield traits, both at an optimum and sub-optimum growing environments. Testing in rain-fed and irrigated areas is required to obtain good traits according to the conditions of environment where they grow, so that the selection can be performed on high yield potential genotypes, although testing is conducted on a small scale.

Testing on a small scale is expected to be able to provide information on preliminary yield of drought-tolerant hybrid rice genotypes and potentially be developed in the rain-fed lowland in a wider scale. The genotypes of rice should be able to adapt and steady at any location in various seasons, so that a genotype can be released as a superior cultivar [8-10]. The study aimed to determine the preliminary yield of new rice hybrid in irrigated lowland and the current drought in the rain-fed lowland.

\section{Materials and Methods}

The experiment growth and yield in irrigated lowland was conducted in November 2011 to February 2012 in irrigated lowland of Bojong, district Cikembar, Sukabumi, West Java, Indonesia. The climate of the study site was moderate with the average temperature of $18-32{ }^{\circ} \mathrm{C}$ and precipitation ranged $1200-2200 \mathrm{~mm} \mathrm{year}^{-1}$. The plant materials used were 8 genotypes/varieties of new hybrid rice i.e. BI485A/BP3, BI485A/BP5, BI485A/BP10, BI485A/B P12, BI485A/BP15, BI599A/BP5, BI599A/BP15, BI665A/ BP6, and two check varieties i.e. Ciherang and Hipa 7. The experiments used a randomized block design with three replications.

Plot size as the unit of experiments was $2.0 \mathrm{~m} \times 1.5 \mathrm{~m}$, the distance between the treatment plots was $50 \mathrm{~cm}$, and between blocks was $100 \mathrm{~cm}$. Seedlings yielded from seedbed were transplanted after at least 21 days, the seedlings were planted with spacing of $25 \mathrm{~cm} \times 25 \mathrm{~cm}$, one seedling per hole. Fertilizing used with $300 \mathrm{~kg}$ Urea, $125 \mathrm{~kg} \mathrm{SP-36}$, and $100 \mathrm{~kg}$ $\mathrm{KCl}$ per hectare. All SP-36 and $\mathrm{KCl}$ fertilizers were given at the time of planting; Urea was given three times at time of planting, 4 weeks and 7 weeks after planting. The control of pests and diseases was done optimally, while weeding was done manually using a push weeder, three and five weeks after planting. Irrigation was adjusted to the character of the rice fields used. Irrigation on irrigated lowland was maintained under optimum conditions during the growth phase until harvest. The height of water on the plots was adjusted to the growth phase of plant. The observation was objected to five clumps of sample plants. Variables measured were plant height, number of productive shoots, panicle length, number of filled grains, total number of grains, the percentage of filled grain, 1000 grain weight, grain weight per hill, days to $50 \%$ flowering and $85 \%$ yellow harvesting and grain yield per plot.

The experiment growth and yield in rain-fed lowland was conducted from April to July 2012 on rain-fed lowland of
Sanca village, subdistrict Gantar, district Indramayu, West Java, Indonesia. The climate in the study areas was hot climate with average temperature of $32-35{ }^{\circ} \mathrm{C}$ and annual rainfall ranged from 1000-2400 $\mathrm{mm}_{\text {year }}{ }^{-1}$.

The plant materials used were 4 genotypes/varieties of new hybrid rice i.e. BI485A/BP3 (drought-sensitive category), BI485A/BP12, BI485A/BP15, and BI599A/BP15 (drought-tolerant category based on the results of previous studies), and 1 hybrid variety, namely HIPA 7 (released-varieties suitable for rain-fed lowland) and two inbred varieties namely IR-64 (drought-sensitive check) and Limboto (drought-tolerant check). The experiments used a randomized block design with three replications. The soil sample was taken to analyze its physical and chemical properties, namely the determination of the water content of the soil at field capacity $(\mathrm{pF} 2.54)$ and permanent wilting point ( $\mathrm{pF}$ 4.20) based on the method of pressure plate/membrane apparatus [11]. The experimental plot size of each treatment unit was $3.00 \mathrm{~m} \times 1.75 \mathrm{~m}$, the distance between treatment plots was $50 \mathrm{~cm}$, and inter-groups distance was $100 \mathrm{~cm}$. Seedlings yielded from seedbed were transplanted after at least 21 days, the seedlings were planted with spacing of $25 \mathrm{~cm} \times 25 \mathrm{~cm}$, one seedling per hole. The observation was directed to five clumps of sample plants. Variables measured were plant height, flag leaf length, number of productive shoots, plant dry weight of the upper part (biomass), 50\% flowering-age, panicle length, number of total grains, percentage of filled grains, grain weight per hill and grain yield per plot.

Data were analyzed using analysis of variance and further test Duncan's Multiple Range test (DMRT) the 0.05 probability level using SAS 9.1 software program.

\section{Results and Discussion}

\section{Rainfall and soil moisture conditions}

The average rainfall in the trial location of irrigated lowland (Table 1) was considered to be sufficient for the rice water requirement of $>200 \mathrm{~mm} / \mathrm{month} \mathrm{[12].Thus,} \mathrm{in-}$ adequacy of irrigation water can be supplied with the rainfall. At well-ripening phase, the amount of rainfall was $<200 \mathrm{~mm}$ and occurred only for eight days, which was sufficient condition to accelerate the maturation of seeds and harvest time.

Table 1: Average rainfall during the growth of hybrid rice in irrigated lowland of Bojong village, Cikembar district, Sukabumi, Indonesia.

\begin{tabular}{l|ccc}
\hline Growing phase $^{\mathbf{b}}$ & $\begin{array}{c}\text { CH } \\
\text { (mm) }^{\mathbf{a}}\end{array}$ & $\begin{array}{c}\text { Rain } \\
\text { frequency } \\
\text { (days) }\end{array}$ & Availability \\
\hline $\begin{array}{l}\text { Planted-Primordial (60 days) } \\
\text { Flowering- Seeds Filling (30 } \\
\text { days) }\end{array}$ & 492.3 & 44.0 & Sufficient \\
Seeds Ripening & 485.6 & 26.0 & Sufficient \\
Well-Ripening & 218.8 & 11.0 & Sufficient \\
\hline
\end{tabular}

Notes: $\mathrm{a}=$ the Board of Meteorology, Climatology and Geophysics, Geophysical Observatory in Pelabuhan Ratu. Sukabumi, Indonesia; b = growing phase of rice varieties was 120 days [13]. 
During the trial in rain-fed lowland, the distribution and frequency of rainfall during the vegetative phase (planting until the primordial) were at insufficient level, only $94.7 \mathrm{~mm}$ and rain occurred only 7 days. Flowering to grain filling phase was at a critical level of $0.6 \mathrm{~mm}$ and rain occurred only 1 day, whereas at well-ripening phase rain did not occur (Table 2). The condition caused the plant experienced a severe drought stress, which occurred in 2 weeks after planting. Result of recorded soil moisture is presented in Figure 1. Level of soil moisture in the field capacity was $38.6 \%$ and permanent wilting point was $26.9 \%$.

Table 2: Average rainfall during the growth of hybrid rice in the rain-fed lowland of Sanca Village, District Gantar, Indramayu, Indonesia.

\begin{tabular}{l|ccc}
\hline Growing phase $^{\mathbf{b}}$ & $\begin{array}{c}\text { CH } \\
(\mathbf{m m})^{\mathbf{a}}\end{array}$ & $\begin{array}{c}\text { Rain } \\
\text { frequency } \\
\text { (days) }\end{array}$ & Availability \\
\hline $\begin{array}{l}\text { Planting-Primordial (60 days) } \\
\text { Flowering-Seeds Filling (30 } \\
\text { days) }\end{array}$ & 94.7 & 7.0 & Insufficient \\
Seeds Ripening & 0.6 & 1.0 & Severe \\
Well-Ripening & $\mathrm{NR}$ & $\mathrm{NR}$ & Severe \\
\hline
\end{tabular}

Notes: $\mathrm{NR}=$ no rain; $\mathrm{a}=$ direct measurement in the field, $\mathrm{b}=$ rice varieties growth phase for 120 days [13].

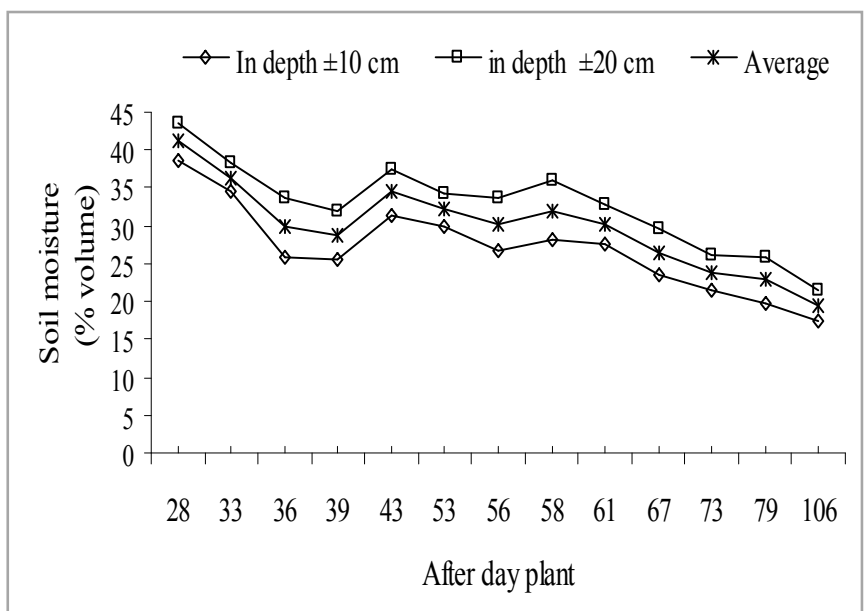

Figure 1: Moisture of soil during the trail in rain-fed lowland rice of Sanca Village, District Gantar, Indramayu, Indonesia, from April to July in 2012.

\section{Growth and yield}

Results of analysis of variance experiment growth and yield in irrigated lowland showed that variety treatment significantly influenced variables of plant height, $50 \%$ flowering age, panicle length, the total grain number, and filled grain, the percentage of empty grains, and 1,000 grain weight, while the variables of number of productive tillers, grain weight per hill and grain yield per hectare were not significantly influenced. Results of DMRT test on average growth are presented in Table $\mathbf{3}$ and the average of yield components and yield are presented in Table 4.

Table 3 shows that most genotypes tested had plant height, which was not significantly different from check varieties of Ciherang and HIPA 7, except for BI599A/BP15, BI599A/BP5, and BI665A/BP6. Genotype BI599A/BP15 was the highest, which was not significantly different from BI599A/BP5. Plant height is significantly associated with lodging. IRRI assigned a standard for the height of new rice type with $100 \mathrm{~cm}$ [14]. Ma et al. [15] confirmed that the ideal crop with lodging resistance ranges from 115 to $120 \mathrm{~cm}$. Therefore, this genotype is an ideal genotype to be developed in the rice field because the height character of the plant was within the ideal prototype standard of lodging resistance.

Table 3: Growth components including plant height $(\mathrm{PH})$, number of productive tillers (NPT), flowering age at $50 \%$ (FA), and harvest age (HA) of hybrid rice genotypes and check varieties in irrigated lowland.

\begin{tabular}{|c|c|c|c|c|}
\hline Genotype & $\begin{array}{l}\text { PH } \\
(\mathbf{c m})\end{array}$ & NPT & $\begin{array}{c}\text { FA } \\
\text { (days) }\end{array}$ & $\underset{\text { (days) }}{\text { HA }}$ \\
\hline BI485A/BP3 & $98.60^{d}$ & 13.3 & $85.3^{\text {de }}$ & $119.7^{\mathrm{a}}$ \\
\hline BI485A/BP5 & $101.80^{\mathrm{cd}}$ & 13.1 & $85.0^{\mathrm{de}}$ & $117.7^{b}$ \\
\hline BI485A/BP10 & $101.33^{\mathrm{d}}$ & 13.0 & $86.3^{\mathrm{cd}}$ & $115.3^{\text {cd }}$ \\
\hline BI485A/BP12 & $100.40^{\mathrm{d}}$ & 12.1 & $85.7^{\text {de }}$ & $116.7^{b c}$ \\
\hline BI485A/BP15 & $103.60^{\mathrm{cd}}$ & 14.8 & $84.7^{\mathrm{e}}$ & $115.0^{\mathrm{d}}$ \\
\hline BI599A/BP5 & $110.33^{a b}$ & 12.9 & $87.3^{c}$ & $118.0^{\mathrm{b}}$ \\
\hline BI599A/BP15 & $114.33^{\mathrm{a}}$ & 13.1 & $86.3^{\mathrm{cd}}$ & $117.7^{b}$ \\
\hline BI665A/BP6 & 107.27 bc & 11.9 & $91.7^{\text {ab }}$ & $121.0^{\mathrm{a}}$ \\
\hline Ciherang & $100.53^{d}$ & 13.7 & $92.3^{\mathrm{a}}$ & $120.0^{\mathrm{a}}$ \\
\hline Hipa 7 & $100.87^{\mathrm{d}}$ & 12.5 & $90.3^{\mathbf{b}}$ & $120.3^{a}$ \\
\hline
\end{tabular}

Notes: Figures followed by the same letter in each of the variables were not significantly different by DMRT at $\alpha=0.05$.

The number of productive tillers among genotypes and the check varieties showed no significant difference. The average number of productive tillers ranged from 12 to 15 (Table 3). Peng et al. [16] stated that the low capacity of tillers for transplanting were 8-10 productive tillers. Furthermore, Peng et al. [17] reported that the super hybrid rice in China had 200-250 productive tillers per $\mathrm{m}^{2}$ (12-15 tillers per hill at a distance of $25 \mathrm{~cm} \mathrm{x} 25 \mathrm{~cm}$ ). Genotypes tested in this research had an average of productive tillers in that range.

Average flowering age among genotypes was not significantly different except for genotype BI665A/BP6 in which the flowering time was 50\% longer, but the flowering time of this genotype was not significantly different from that of check varieties, Ciherang and HIPA 7. Generally the tested-genotypes were faster in flowering, i.e. 85.0-87.3 days while flowering age of check varietiess Ciherang and Hipa7 were 92.3 and 90.3 days, respectively (Table 3). Age of flowering strongly relates to the efficiency of the utilization of water resources and nutrients because the phase of vegetative growth is shorter. The shorter age of flowering generally has good adaptability to drought by accelerating the maturation of grain [18].

The average harvest age of the tested-genotypes was significantly different from that of check varieties, except for genotype BI485A/BP3 and BI665A/BP6. The average harvest age of the tested-genotypes ranged from 115.0 to 121.0 days. In general, hybrid rice genotypes had earlier-maturing age of 120 days than checks varieties (Table 3). Differences in environmental factors cause different plant life cycle. Yoshida [13] stated that the difference in maturity is mostly determined by the phase length of the vegetative growth because the length of the reproductive phase and ripening is not influenced by the environment.

Average of panicle length between genotypes and check varieties was not significantly different. Panicle length of genotypes ranged from 23.82 to $26.47 \mathrm{~cm}$, while the check 
variety Ciherang was $23.7 \mathrm{~cm}$ and HIPA 7 was $25.35 \mathrm{~cm}$ (Table 4). Panicle length generally correlates with the number of grains per panicle. Zang et al. [19] confirmed that large panicles with the huge number of grains per panicle can increase the density of grain.

Table 4: Yield and yield components including panicle length (PL), total grain number (TGN), filled grain number (FGN), filled grain percentage (FGP), 1000 grain weight $(\mathrm{GW})$, grain weight per hill (GWH), and grain yield (GY) of hybrid rice genotypes and check varieties in irrigated lowland.

\begin{tabular}{|c|c|c|c|c|c|c|c|}
\hline Genotype & $\begin{array}{l}\text { PL } \\
(\mathrm{cm})\end{array}$ & $\begin{array}{c}\text { TG } \\
\text { (grain) }\end{array}$ & $\begin{array}{c}\text { FGN } \\
\text { (grain) }\end{array}$ & $\begin{array}{l}\text { FGP } \\
(\%)\end{array}$ & $\begin{array}{l}\text { GW } \\
\text { (g) }\end{array}$ & $\begin{array}{c}\text { GWH } \\
\text { (g) }\end{array}$ & $\begin{array}{c}\text { GW } \\
\left(\operatorname{ton} \mathbf{h a}^{-1}\right)\end{array}$ \\
\hline BI485A/BP3 & 24.88 & $180.9^{\mathrm{bc}}$ & $134.0^{\mathrm{bcd}}$ & $74.4^{\mathrm{cd}}$ & $28.98^{c}$ & 41.13 & 6.5 \\
\hline BI485A/BP5 & 23.82 & $149.1^{\mathrm{d}}$ & $118.4^{\mathrm{d}}$ & $79.7^{\mathrm{bc}}$ & $28.93^{\mathrm{cd}}$ & 37.11 & 5.93 \\
\hline BI485A/BP10 & 24.54 & $161.7^{\mathrm{cd}}$ & $126.9^{\mathrm{bcd}}$ & $78.5^{\text {bcd }}$ & $29.19^{b c}$ & 39.43 & 6.30 \\
\hline BI485A/BP12 & 25.15 & $173.7^{\mathrm{bcd}}$ & $153.6^{\mathrm{ab}}$ & $88.5^{\mathrm{a}}$ & $29.26^{\text {bc }}$ & 35.25 & 5.63 \\
\hline BI485A/BP15 & 24.66 & $175.8^{\mathrm{bcd}}$ & $147.6^{\mathrm{abc}}$ & $83.7^{\mathrm{ab}}$ & $28.53^{\mathrm{cde}}$ & 42.92 & 6.87 \\
\hline BI599A/BP5 & 25.31 & $171.7^{\mathrm{bcd}}$ & $142.6^{\mathrm{abcd}}$ & $82.7^{\mathrm{abc}}$ & $30.88^{\mathrm{a}}$ & 38.94 & 6.23 \\
\hline BI599A/BP15 & 24.49 & $169.5^{\text {bcd }}$ & $135.3^{\mathrm{bcd}}$ & $79.3^{b c}$ & $29.86^{\mathrm{b}}$ & 39.40 & 6.30 \\
\hline BI665A/BP6 & 26.47 & $219.2^{\mathrm{a}}$ & $162.9^{\mathrm{a}}$ & $74.0^{\mathrm{cd}}$ & $28.59^{\mathrm{cd}}$ & 33.92 & 5.43 \\
\hline Ciherang & 23.69 & $153.0^{\mathrm{cd}}$ & $125.8^{\mathrm{d}}$ & $82.1^{a b c}$ & $28.16^{\mathrm{de}}$ & 38.30 & 6.13 \\
\hline Hipa 7 & 25.35 & $195.0^{\mathrm{ab}}$ & $140.3^{\mathrm{abcd}}$ & $71.8^{\mathrm{d}}$ & $27.99^{\mathrm{e}}$ & 46.81 & 7.50 \\
\hline
\end{tabular}

Notes: The numbers followed by the same letter for each variable were no significantly different by DMRT at $\alpha=0.05$.

The grain number per panicle was significantly different between genotypes. The average number of grains was high in genotype BI665A/BP6 (219.2 grains) that was significantly different from that of the check variety Ciherang (153.0 grains) (Table 4). A relatively high number of total grain on hybrid genotypes is as the implication of the long panicles of hybrid rice genotypes [19].

The number of filled grains was significantly different between genotypes and check varieties. Genotype BI665A/BP6 yielded the highest number of filled grains, followed by genotype BI485A/BP12, BI485A/BP15, and BI599A/BP5 of 162.9, 153.6, 147.6, and 142.6 grains, respectively, but was not significantly different from the check variety HIPA 7 of 140.3 grains. The number of filled grains of check variety Ciherang was only 125.8 grains which was significantly different from genotypes BI665A/BP6, BI485A/BP12, and BI485A/BP15, but not significantly different from the other genotypes. The average number of filled grains of hybrid genotypes ranged between 118.4-162.9 grains, while the check varieties Ciherang and HIPA 7 had averages of 125.8 grains and 140.3 grains, respectively (Table 4). Peng and Khush [20] stated that the criterion for a higher yield was the number of grains per panicle of about 150 grains.

The highest percentage of filled grains obtained in genotype BI485A/BP12 of $88.5 \%$, which was not significantly different from those of BI485A/BP15, BI599A/BP5, and check variety Ciherang i.e. 83.7, 82.7, and $82.1 \%$, respectively. Genotype with the lowest percentage of filled grains was BI665A/BP6 of $74.0 \%$ which was not significantly different from genotypes BI485A/BP3, $\mathrm{BI} 485 \mathrm{~A} / \mathrm{BP} 10$, and check variety HIPA 7 , i.e. of $74.4,78.5$, and $71.8 \%$, respectively (Table 4). The grain filling process is determined by the source in supporting sink or due to the aging process. The limited resources in supporting sink due to the low accumulation of photosynthate or earlier aging process will increase the empty grains percentage. Abdullah et al. [21] reported that one of the causes of a void is the imbalance between the sink and the source. Dry matter in the leaves started to decrease in 10 days after seed filling, and relatively large leaves play an important role in supplying photosynthate to seeds [22]

The highest 1000 grain weight was obtained in genotype BI599A/BP5 of $30.88 \mathrm{~g}$, followed by genotype BI599A/BP15, which was not significantly different from those of genotype BI485A/BP10 and BI485A/BP12 i.e. $29.19 \mathrm{~g}$ and $29.26 \mathrm{~g}$, respectively (Table 4). Ma et al. [15] stated that trait of ideal plant had panicle with 1000 grain weight of 28-30 g. A new type of rice with grain weight of 28-30 g, panicle length $>26 \mathrm{~cm}$ and lots of grains is a fair size for sink to support high grain yield. Plants with a lot of grains per panicle need much assimilate for grain filling, so it should be supported by ideal leaf traits i.e. medium leaf width, thick, slightly dropping, not rapidly aging and medium age, as in genotype BI485A/BP12, BI485A/BP15, BI599A/BP5, and BI599A/BP15.

The weight of grains per hill between genotypes and check varieties were not significantly different. The weight of grains per hill among genotypes ranged from 33.92-42.92 $\mathrm{g}$, grain weight per hill of check variety Ciherang was $38.30 \mathrm{~g}$ and $46.81 \mathrm{~g}$ for HIPA 7. The grain weight of the genotypes when converted to yield ranged from 5.43 to 6.87 ton $\mathrm{ha}^{-1}$. Genotype BI485A/BP15 had the highest grain yield of 42.92 $\mathrm{g}$ hill $^{-1}$ or 6.87 tons ha-1 (Table 4). Virmani et al. [23] suggested that important benchmark in the assembly of hybrid rice is the yield comparison between hybrids and check varieties. Genotype BI485A/BP3, BI485A/BP10, $\mathrm{BI} 485 \mathrm{~A} / \mathrm{BP} 15$, and BI599A/BP15, when compared to the check variety Ciherang was likely to show an increase i.e. 7.2, 2.8, 12.1, 1.6, and 2.8 percent, respectively (Table 4).

An effective way to develop a lowland rice cultivar with high yield potential in both the optimum and sub optimum conditions (drought stress) is through direct selection that can combine the selection in irrigated and rain-fed lowlands. Therefore, a preliminary yield trial of drought-tolerant hybrid genotypes was performed, which was potential to be developed in the rain-fed areas.

Results of analysis of variance experiment growth and yield in rain-fed lowland showed that the variety treatment significantly influenced variables of plant height, flag leaf length, weight of biomass, $50 \%$ flowering age, panicle length, number of total grains, the percentage of filled grains, grain weight per hill and yield per hectare, but had no significant effect on the variables of productive tillers. Results of DMRT test on the growth variables are presented in Table $\mathbf{5}$ and on the yield components and the yield are presented in Table 6.

Table 5 shows that the tallest plant height was obtained on genotype BI599A/BP15, which was not significantly different from check variety Limboto, but significantly different from the check varieties IR64 and HIPA 7. Genotypes BI485A/BP3, BI485A/BP12, and BI485A/BP15 were not significantly different from the check varieties IR64 and HIPA 7, but significantly different from the check variety Limboto. The low rainfall and rain frequency since the vegetative phase strongly inhibited the growth of plant height, that was only of 54.67 to $82.11 \mathrm{~cm}$ because cell division was inhibited [24]. Consequently, due to drought 
stress in rain-fed areas, the average plant height of genotypes was lower than the standard height for a new type rice crop of $100 \mathrm{~cm} \mathrm{[14],} \mathrm{and} \mathrm{different} \mathrm{with} \mathrm{plant} \mathrm{height} \mathrm{on} \mathrm{trial} \mathrm{in}$ irrigated lowland. However, drought-tolerant genotypes BI599A/BP15 could still achieve $82.11 \mathrm{~cm}$ in height, which was relatively equal to check variety Limboto of $81.11 \mathrm{~cm}$. Samaullah and Darajat [25] stated that the limited supply of water can suppress plant growth by $10-25 \mathrm{~cm}$ in a drought-stress growing environment. Kumar et al. [26] reported that at severe drought conditions, the decrease in plant height on tolerant strains reached $6-12 \mathrm{~cm}$, and on sensitive strains reached $16-27 \mathrm{~cm}$.

Table 5: Growth components including plant height $(\mathrm{PH})$ number of productive tillers (NPT), flowering age (FA), and total biomass (TB) of hybrid rice genotypes and check varieties in rain-fed lowland.

\begin{tabular}{l|lccl}
\hline \multicolumn{1}{c|}{ Genotype } & $\begin{array}{c}\text { PH } \\
\text { (cm) }\end{array}$ & NPT & $\begin{array}{c}\text { FA } \\
\text { (days) }\end{array}$ & $\begin{array}{l}\text { TB } \\
\text { (g) }\end{array}$ \\
\hline BI485A/BP3 & $68.33^{\mathrm{bc}}$ & 11.1 & $88^{\mathrm{a}}$ & $27.38^{\mathrm{b}}$ \\
BI485A/BP12 & $67.44^{\mathrm{bc}}$ & 11.6 & $83^{\mathrm{b}}$ & $32.95^{\mathrm{ab}}$ \\
BI485A/BP15 & $64.56^{\mathrm{c}}$ & 11.7 & $86^{\mathrm{ab}}$ & $28.53^{\mathrm{ab}}$ \\
BI599A/BP15 & $82.11^{\mathrm{a}}$ & 13.4 & $83^{\mathrm{b}}$ & $34.67^{\mathrm{a}}$ \\
IR64 & $54.67^{\mathrm{c}}$ & 12.9 & $85^{\mathrm{ab}}$ & $19.07^{\mathrm{c}}$ \\
Limboto & $81.11^{\mathrm{ab}}$ & 9.8 & $82^{\mathrm{b}}$ & $34.69^{\mathrm{a}}$ \\
Hipa 7 & $63.56^{\mathrm{c}}$ & 10.4 & $83^{\mathrm{b}}$ & $26.77^{\mathrm{b}}$ \\
\hline
\end{tabular}

Notes: The numbers followed the same letter for each variable were not significantly different by DMRT test at $\alpha=0.05$.

The number of productive tillers did not significantly differ among genotypes and check varieties. The average number of productive tillers ranged from 10 to 13 (Table 5). This suggests that the formation and growth of tillers were not affected by drought-stress. The genotypes had an average of productive tillers that was suitable for transplanting, i.e. 8-10 [16]. The shortest average flowering -age was obtained in check variety Limboto, which was not significantly different with genotypes BI599A/BP15, BI485A/BP12, and HIPA 7. The longest average flowering -age was obtained in genotype BI485A/BP3, which was not significantly different from genotypes BI485A/BP15 and check variety IR64 (Table 5). Flowering age is strongly related to the efficiency of the utilization of water resources and nutrients due to shorter vegetative growth phase. Shorter flowering-age generally has good adaptability to drought and is able to accelerate ripening of grains. Kumar et al. [26] stated that in conditions of severe drought, tolerant strains accelerated flowering by \pm 8 days compared with sensitive strains. Samaullah and Darajat [25] and Ahadiyat et al. [27] reported that the earlier-flowering genotype with a little number of empty grains in a water-stress environment has a drought-tolerant trait. The lateness in flowering of genotypes growing in drought-stress environment will shorten the grain filling phase, which affects the yield.

The highest average total biomass (plant dry weight) was obtained on genotype BI599A/BP15, which was not significantly different from genotypes BI485A/BP12 and BI485A/BP15, but significantly different from BI485A/BP3. The genotypes with the highest plant dry weight had relatively equal weights with check variety Limboto but significantly different with check variety IR64 (Table 5). Kumar et al. [26] stated that the total dry substance of late-flowering genotypes gradually declines in drought stress conditions. This indicates that the late-flowering plants may stop early growing phase during the growth cycle causing the dry weight decreases. Genotypes BI599A/BP15, BI485A/ $\mathrm{BP} 12$, and BI485A/BP15 had a relatively shorter flowering -age, so that produced relatively higher dry weight in severe drought conditions. Kumar et al. [28] reported that the tolerant strains have the ability to maintain high biomass production in dry soil and high harvest index.

Average of panicle length of hybrid genotypes and check varieties HIPA 7 and Limboto was significantly different from the check variety IR64. The IR64 has the lowest panicle length of $17.9 \mathrm{~cm}$, while the length panicle of genotypes ranged from 20.9-21.8 cm (Table 6). Severe drought conditions inhibited panicle length of check variety IR64, which was sensitive to drought because the panicles exertion was hampered. This lead some grains to stay in the leaf midrib and become sterile grains, causing the decreasing of grain yield [29]. Panicle length generally correlated positively with the number of grains per panicle [19].

Total number of grains was fairly high on genotype BI485A/BP3 but was not significantly different from genotype BI599A/BP15, of 137.5 and 123.6 grains, respectively. The number of total grains of the genotypes was still lower than that of the check variety Limboto of 153.6 grains, but higher than those of the check varieties HIPA 7 and IR64, of 111.7 and 64.7 grains, respectively (Table 6). The high total number of grains per panicle should be supported by a sufficient source for better grain filling [30].

Table 6: Yield components and the yield including panicle length (PL), total grain number of panicle (TGNP), filled grain percentage (FGP), hill grain weight (HGW), and grain yield (GY) of hybrid rice genotypes and check varieties in rain-fed lowland.

\begin{tabular}{l|ccccc}
\hline Genotype & $\begin{array}{c}\text { PL } \\
\text { (cm) }\end{array}$ & $\begin{array}{c}\text { TGNP } \\
\text { (butir) }\end{array}$ & $\begin{array}{c}\text { FGP } \\
(\%)\end{array}$ & $\begin{array}{c}\text { HGW } \\
\text { (g) }\end{array}$ & $\begin{array}{c}\text { GY } \\
\text { (ton ha } \mathbf{~ h}^{-1}\end{array}$ \\
\hline BI485A/BP3 & $21.43^{\mathrm{a}}$ & $137.5^{\mathrm{ab}}$ & $3.3^{\mathrm{b}}$ & $0.54^{\mathrm{b}}$ & $0.09^{\mathrm{b}}$ \\
$\mathbf{B I 4 8 5 A / B P 1 2}$ & $20.89^{\mathrm{a}}$ & $106.2^{\mathrm{cd}}$ & $13.1^{\mathrm{ab}}$ & $0.97^{\mathrm{b}}$ & $0.16^{\mathrm{b}}$ \\
$\mathbf{B I 4 8 5 A / B P 1 5}$ & $20.86^{\mathrm{a}}$ & $100.5^{\mathrm{d}}$ & $13.9^{\mathrm{ab}}$ & $1.21^{\mathrm{b}}$ & $0.19^{\mathrm{b}}$ \\
$\mathbf{B I 5 9 9 A / B P 1 5}$ & $21.80^{\mathrm{a}}$ & $123.6^{\mathrm{bc}}$ & $30.9^{\mathrm{a}}$ & $5.62^{\mathrm{a}}$ & $0.90^{\mathrm{a}}$ \\
$\mathbf{I R 6 4}$ & $17.78^{\mathrm{b}}$ & $64.7^{\mathrm{e}}$ & $10.3^{\mathrm{b}}$ & $1.16^{\mathrm{b}}$ & $0.19^{\mathrm{b}}$ \\
Limboto & $20.98^{\mathrm{a}}$ & $153.6^{\mathrm{a}}$ & $7.5^{\mathrm{b}}$ & $1.79^{\mathrm{b}}$ & $0.29^{\mathrm{b}}$ \\
Hipa 7 & $21.16^{\mathrm{a}}$ & $111.7^{\text {cd }}$ & $14.4^{\mathrm{ab}}$ & $2.11^{\mathrm{ab}}$ & $0.34^{\mathrm{ab}}$ \\
\hline
\end{tabular}

Notes: The numbers followed the same letter for each variable were not significantly different by DMRT test at $\alpha=0.05$.

In general, the percentage of filled grain of genotypes was very low, ranging from 3.3 to 30.9 percent. Genotype BI599A/BP15 had the highest percentage of filled grain of 30.9 percent which was not significantly different from genotypes BI485A/BP12, BI485A/BP15 and HIPA 7, but significantly different from genotypes BI485A/BP3, IR64 and Limboto. The lowest percentage of filled grain (3.3 percent) was achieved by genotype BI485A/BP3. The percentage of filled grain of check varieties IR64 and Limboto was relatively low, of 10.3 and 7.5 percent, respectively (Table 6). A severe drought led to the source being interrupted, thus the seed filling stage highly depended on the nature and mechanisms of plants coping with the drought stress. The higher percentage of filled grain on genotype BI599A/BP15 was caused by the earlier-flowering trait. Pantuwan et al. [31] stated that drought escape mechanism of early-maturity genotypes with high yield in long drought-stress conditions was possibly due to the pre-anthesis assimilate contribution as a source of assimilates 
during the grain filling period. In severe drought conditions, empty grains in CT9993 drought-tolerant strain reached 71 percent, while in IR62266 drought-sensitive strain reached 91 percent [28].

Grain weight of genotypes per hill ranged from 0:54 $5.62 \mathrm{~g}$ per hill. A high percentage of filled grains led to a high yield or grain weight per hill. Therefore, genotype BI599A/BP15 had the highest grain weight of $5.62 \mathrm{~g}$ per hill or 0.90 tons of grain yield per hectare which was not significantly different from hybrid variety HIPA 7 but significantly different from the other genotypes and check varieties IR64 and Limboto. HIPA 7 was recommended to be planted in rain-fed areas [32]. The lowest grain weight was obtained on genotype BI485A/BP3 of 0:54 g per hill, but was not significantly different from those of the three check varieties and genotypes BI485A/BP12 and BI485A/BP15 (Table 6).

Grain yield obtained in genotype BI599A/BP15 was equal to the grain yield obtained in strain CT9993, which is a drought tolerant genotype when was grown in a severe drought conditions in Raipur, Northeast region of India. Strain CT9993 was only able to produce 0.95 tons per hectare [28]. The difference in yield of genotype BI599A/BP15 and other genotypes may be due to differences in the contribution of pre-anthesis dry matter to seed production. The genotypes had a relatively shorter flowering-age, thus, it produced a higher dry weight in severe drought conditions (Table 5). Therefore, early-ripening genotype BI599A/BP15 that was able to reallocate reserved assimilates from the stem to the seed under drought condition resulted in a high yield. This mechanism involves rapid phenological development (early flowering and early ripening) and pre-anthesis assimilates remobilization [33].

Limboto is a drought-tolerant variety. During the growing in the field in a severe drought conditions, Limboto maintained a high level of leaf greenness but grain filling rate was much lower than the genotypes BI599A/BP15 (Figure 2 and Table 6). Fukai and Cooper [34] confirmed that there are four trait categories of drought resistance of rain-fed rice i.e. drought escape, drought avoidance, drought tolerance and drought recovery after a drought occurred. Fukai et al. [35] stated that the maintenance of leaf greenness in drought conditions is an example of the adaptation mechanisms of drought tolerance of rain-fed rice. Drought escape is a effective strategy to reduce the unfavorable effects of drought that adjusts the availability of water with plant phenology [36].

Thus, Limboto leaf greenness in severe drought conditions in which rain only occurred the first two weeks after planting indicated that Limboto variety is a drought tolerant, whereas genotype BI599A/BP15 developed more than one mechanism or adaptation strategies namely drought escape and drought tolerance. In drought conditions, genotype BI599A/BP15 was not only accelerated flowering/harvest (Table 5) but also had a low density of stomata and still maintained relative moisture of leaves at a high level in drought conditions [37-39]. Mitra [33] confirmed that plants often used more than one mechanism for drought tolerance. Thus, genotype BI599A/BP15 was able to produce better grain in drought conditions than other genotypes.

Therefore the hybrid rice genotype that is potential for further development in the rain-fed lowland and also in irrigated lowland with high yield potential and early-maturity age is genotype BI599A/BP15. Genotype BI599A/BP15 that experienced drought stress, in the critical phase was capable of producing 2.72 tons of grain per hectare, whereas IR64 produced only 1:42 tons per hectare of grain [37]. This offers an opportunity that genotype BI599A/BP15 can be planted under conditions of rainfall restriction but not continuous drought during the vegetative to reproductive phase. On the other hand, when an unpredictable severe drought occurred, farmers can still obtain yields even though the productivity was $<1$ ton per hectare (Table 6). These efforts can improve cropping index in the rain-fed lowland.

\section{Conclusion}

Based on the condition of the field test, the following points can be concluded:

1. On irrigated lowland, all tested-genotypes produced grain weight per hill and grain yield per hectare, which was not significantly different from the check varieties Ciherang and HIPA 7.

2. Drought-tolerant genotypes BI485A/BP12, BI485A/BP15, and BI559A/BP15, in irrigated lowland had equal yields with that of variety Ciherang, of 5.63, 6.87 and 6.30 tons per hectare, respectively.

3.Genotype BP599A/BP15, at a very severe drought conditions in the rain-fed lowland, generally produced better results than other genotypes for plant height, productive tillers, flag leaf length, total biomass, panicle length, filled grain percentage and grain weight per hill.

4.Genotype BP599A/BP15 at a very severe drought conditions in the rain-fed lowland was able to produce 0.90 tons of grain per hectare, while HIPA 7 (hybrid variety that had been released to the rain-fed lowland) and Limboto (drought-tolerant check variety) produced only $0: 34$ and 0:29 tons per hectare, respectively.

5.Genotype BI599A/BP15 is a new hybrid genotype that potential for advanced development in rain-fed lowland and also in irrigated lowland with a high yield potential and quiet early-maturity age.

\section{Acknowledgments}

Acknowledgement was submitted to the Agency for Agricultural Research, Ministry of Agriculture for funding this research through KKP3T in fiscal year 2012 to Bambang S. Purwoko and team.

\section{Author Contributions}

L. Afa conducted field experimental tests and data analysis. B. S. Purwoko, A. Junaedi, O. Haridjaja and S. S. Dewi formulated experimental design, helped in preparing the draft of reports and made some correction on the manuscript.

\section{References}

1.Virmani SS, Kumar I. Development and use of hybrid rice technology to increase rice productivity in the tropics. International Rice Research Notes. 2004;29(1): 10-19. 
2.Huang $\mathrm{M}$, Tang Q, Ao H, Zou Y. Yield potential and stability in super hybrid rice and its production strategies. Journal of Integrative Agriculture. 2017;16(5):1009-1017.

3. Yuan L. Development of super hybrid rice for food security in China. Engineering. 2015;1:13-14.

4.Suprihatno B. Hybrid Rice. In: Ismunadji M, Syam M, Yuswadi, editors. Rice Book 2. Agricultural Development and Research Agency. Center for Food Crops Research and Development. Bogor; 1989.p.377-390.

5.Villa JE, Henry A, Xie F, Serraj R. Hybrid rice performance in environments of increasing drought severity. Field Crops Research. 2011;125:14-24.

6.Afa L, Purwoko BS, Junaedi A, Haridjaja O, Dewi IS. Simulation of hybrid rice tolerance to drought stress on nutrients culture in seedling phase. Bioscience research. 2018;15(1): 530-539.

7.Afa L, Purwoko BS, Junaedi A, Haridjaja O, Dewi IS. Screening of hybrid rice tolerance through stimulated condition of drought stress in rain-fed lowland. Bioscience research. 2018;15(3): 1630-1637.

8.Harsanti L, Hambali, dan Mugiono. Analysis of adaptability paddy 10 genotype mutant in 20 locations yield trials in two seasons. Zuriat. 2003;14(1):1-7.

9. Swain P, Raman A, Singh SP, Kumar A. Breeding drought tolerant rice for shallow rain-fed ecosystem of Eastern India. Field Crops Research. 2017;209:168-178. doi:10.1016/j.fcr.2017.05.007.

10.Dewi ER, Whitbread AM. Use of Climate Forecast Information to Manage Lowland Rice-Based Cropping Systems in Jakenan, Central Java, Indonesia. Asian Journal of Agricultural Research. 2017;11:66-77.

11.Sudirman SS, Juarsah I. Determination of soil water retention in the laboratory. In: Kurnia U, Agus F, Adimihardja A, Dariah A, editors. Soil Physical Properties and Methods of analysis. Center for Research and Development of Agricultural Land Resources. Agricultural Development and Research Agency; 2006.p.167-176.

12.Fagi AM, Las I. Rice Growing Environment. In: Ismunadji M, Syam M, Yuswandi, editors. Rice Book 1. Center for Food Crops Research and Development Bogor; 1998.p.215-230.

13.Yoshida S. Fundamentals of Rice Crop Science. International Rice Research Institute, Los Baños, Laguna, Philippines; 1981.

14.Peng S, Khush GS, Virk P, Tang Q, Zou Y. Progress in ideotype breeding to increase rice yield potential. Field Crops Research. 2008;108:32-38.

15.Ma J, Ma WB, Ming DF, Yang SM, Zhu QS. Characteristics of rice plant with heavy panicle. Agricultural Sciences in China. 2006;5: 911-918.

16.Peng S, Khush GS, Cassman KG. Evaluation of a new plant ideotype for increased yield potential. In: Cassman KG, editor. Breaking the Yield Barrier. Proceedings of a Workshop on Rice Yield Potential in Favorable Environments. Los Banos, Philippines: International Rice Research Institute; 1994.p.5-20.

17.Peng S, Laza1 RC, Visperas RM, Khush GS, Virk P, Zhu D. Rice: progress in breaking the yield ceiling. In: New Direction for a Diverse Planet. Proceedings of the $4^{\text {th }}$ International Crop Science Congress. Sept 26-Oct 1, 2004. Brisbane Australia; 2004.
18.Lafitte HR, Li ZK, Vijayakumar CHM, Gaob YM, Shi Y, $\mathrm{Xu} \mathrm{JL}, \mathrm{Fu} \mathrm{BY}$, et al. Improvement of rice drought tolerance through backcross breeding: Evaluation of donors and selection in drought nurseries. Field Crops Research. 2006;97:77-86.

19.Zang H, Tan GL, Xue YG, Liu LJ, Yang JC. Changes in grain yield and morphological and physiological characteristics during 60-year evolution of Japonica rice cultivars in Jiangsu. Acta Agronomica Sinica. 2010;36:133-140.

20.Peng S, Khush GS. Four decades of breeding for varietal improvement of irrigated lowland rice in the International Rice Research Institute. Plant Production Science. 2003;6:157-164.

21.Abdullah B, Dewi IS, Safitri SH, Lestari AP. Assembling a new type of rice through the repeated cross selection and anther culture. Food Crops Agriculture Research. 2008;27(1):1-8.

22. Shigenori O, Amane M, Tadahiko M. Effect of irradiance on the partitioning of assimilated carbon during the phase of grain filling in rice. Annals of Botany. 2003;92:357-364.

23.Virmani SS, Viraktamath BC, Casal CL, Toledo RS, Lopez MT, Manalo JO. Hybrid Rice Breeding Manual. IRRI. Los Banos. Laguna. Philippines; 1997.151 p.

24.Nonami H. Plant water relations and control of cell elongation at low water potentials. Journal of Plant Research. 1998;111:373-382.

25.Samaullah MY, Darajat AA. Upland rice genotypes tolerance to drought stress. Research Agriculture. 2001;20 (1): 17-23.

26.Kumar A, Verulkar S, Dixit S, Chauhan B, Bernier J, Venuprasad R, et al. Yield and yield-attributing traits of rice (Oryza sativa L.) under lowland drought and suitability of early vigor as a selection criterion. Field Crops Research. 2009;114:99-107.

27.Ahadiyat YR, Hidayat P, Susato U. Drought tolerance, phosphorus efficiency and yield characters of upland rice lines. Emirates Journal of Food and Agriculture. 2014;26(1): 25-34.

28.Kumar R, Venuprasad R, Atlin GN. Genetic analysis of rain-fed lowland rice drought tolerance under naturally-occurring stress in estern India: Heritability and QTL effects. Field Crops Research. 2007;103:42-52.

29.Ji XM, Raveendran M, Oane R, Ismail A, Lafitte R, Bruskiewich R, Cheng SH, Bennett J. Tissue-spesific expression and drought responsiveness of cell wall invertase gene of rice at flowering. Plant Molecular Biology. 2005;59:945-964.

30.Jun MA, Wen-bo MA, Ming DF, Yang SM, Zhu QS. Characteristics of rice plant with heavy panicle. Agricultural Sciences in China. 2006;5:911-918.

31.Pantuwan G, Fukai S, Cooper M, Rajatasereekul S, O'Toole JC. Yield response of rice (Oryza sativa L.) genotypes to drought under rain-fed lowland 3. Plant factors contributing to drought resistance. Field Crops Research. 2002;73:181-200.

32.Suprihatno B, Daradjat AA, Satoto, Baehaki SE, Suprihanto, Setyono A, Indrasari SD, Wardana IP, Sembiring H. Description Rice Varieties. Rice Research Institute. Agricultural Development and Research Agency; 2011.p.118. 
33.Mitra J. Genetic and genetic improvement of drought resistance in crop. Plant Science Current Research. 2001;80:758-763.

34.Fukai S, Cooper M. Development of drought-resistant cultivars using physio-morphological traits in rice. Field Crops Research. 1995;40:67-68.

35.Fukai S, Pantuwan G, Jongdee B, Cooper M.Screening for drought resistance in rain-fed lowland rice. Field Crops Research. 1999;64:71-74.

36. Mitchell JH, Siamhan D, Wamala MH, Risimeri JB, Chinyamakobvu E, Henderson SA, Fukai S. The use seedling leaf death score for evaluation of drought resistance of rice. Field Crops Research. 1998;55:129-139.

37.Afa L. Selection of Hybrid Rice to Drought for Development in rain-fed Lowland [Thesis]. Bogor (Indonesia):Bogor Agriculture Institute; 2013.

38.Huang M, Shan S, Cao F, Zou Y. The solar radiationrelated determinants of rice yield variation across a wide range of regions. Wageningen Journal of Life Sciences. 2016;78: 123-128.

39.Huang M, Shan S, Zhou X, Chen J, Cao F, Jiang L, Zou Y. Leaf photosynthetic performance related to higher radiation use efficiency and grain yield in hybrid rice. Field Crops Research. 2016;193: 87-93. 